MATEC Web of Conferences 25, 01013

(2015)

DOI: $10.1051 /$ matec conf/ 20152501013

(c) Owned by the authors, published by EDP Sciences, 2015

\title{
Research on Local Scour at Bridge Pier under Tidal Action
}

\author{
Jianping Wang \\ Pearl River Hydraulic Research Institute of Pearl River Water Resources Commission of the Ministry of Water \\ Resources, Guangzhou, Guangdong, China
}

\begin{abstract}
Through the local scour test at bridge pier under tidal action in a long time series, this paper observes the growing trend of the deepest point of local scour at bridge pier under tidal conditions with different characteristic parameters, analyzes the impact of repeat sediment erosion and deposition in the scouring pit caused by reversing current on the development process of the scouring pit, and clarifies the relation between the tide and local scouring depth at bridge pier under steady flow conditions, so as to provide a scientific basis for bridge design and safe operation of estuary and harbor areas.
\end{abstract}

Keywords: local scour; bridge pier; tide

\section{RESEARCH BACKGROUND}

The local scour of river bed around the bridge pier is affected by water flow state, bridge pier form, bed sand composition, river bed form and other factors. The maximum scouring depth directly threatens the safety of pier foundation ${ }^{[1]}$. The book, Hydrological Specifications for Survey and Design of Highway Engineering ${ }^{[2]}$ (hereinafter referred to as Specifications) recommends the calculation method of scour at bridge pier in runoff river. With the development of national road network and improvement of highway design level, the road has been extended to the tidal river and offshore harbor. So the relevant content in the current Specifications could not meet the actual requirements.

For the local scour at bridge pier under tidal action, in most cases, it is generalized into a constant flow test under limiting conditions ${ }^{[3]-[6]}$. In few cases, the inconstant flow test is given for specific projects ${ }^{[7]-[12]}$. However, there is a divergence in the development course and the maximum depth of local scouring pit at bridge pier under tidal action. The consistency between the maximum flow rate of ebb and flow tide and the mean flow rate of constant flow is a reference condition. One viewpoint believes that under the action of reverse flow, there are sediment erosion and deposition in the scouring pit, resulting that the maximum scouring depth is less than the maximum scouring depth under the action of constant flow. The other viewpoint believes that if the flow velocity is small, and the slack water period is longer in a tidal cycle, the effective acting time and effective acting velocity of flow will decrease, resulting that the formation of scouring pit is slow. Before the scour reaching an equilibrium state, the maximum scouring depth observed is less than the maximum scouring depth under the action of constant flow. However, both of the maximum scouring depth is basically the same.

\section{MODEL DESIGN AND CONSTRUCTION}

\subsection{Model design}

The test is carried out in a water tank, with the length of $35 \mathrm{~m}$ and width of $2 \mathrm{~m}$. Due to little impact of suspended sediment on local scour at bridge pier, the movable bed model only considers bed sand. The plane scale of the model is 100 , which is designed by the use of normal model according to the gravity similarity criterion and geometric similarity criteria, so as to meet the similarity of water flow movement and similarity of sediment movement.

The bridge pier type adopts common pile groups with pile caps in the tidal river and harbor area. The pile group is arranged as quincunx, and the pile cap is dumb-bell shaped. During the test, the pile cap at the upper part of the pile group is always under the action of water flow. The model adopts the multiple-pump frequency-control closed loop water level control system. The system regulates and controls over the output frequency of transducer according to the given flow or hydrograph, regulates water yield of the water pump model to produce fluctuation tide, and make the flow rate and water level in the water tank meet the test requirements. The development process of the maximum depth of local scour is monitored by the ultrasonic sounder.

Scouring duration control: According to the test observation, the scouring depth has reached about $70 \%$ within half an hour under the condition of constant flow. Later, the development speed of the scouring depth is significantly reduced. The scouring pit tends to be stable after 2 to 4 hours (it's related to the size of flow velocity). The scouring duration of the reciprocating flow is unequal (the maximum period of model scour is 28 hours, which is equivalent to 772.8 hours of prototype). When the maximum depth of scouring pit does not have significant changes, the local scour reaches equilibrium.

This is an Open Access article distributed under the terms of the Creative Commons Attribution License 4.0, which permits unrestricted use, distribution, and reproduction in any medium, provided the original work is properly cited. 


\section{MATEC Web of Conferences}

\subsection{Selection of model sand}

The movable bed model must ensure that the sediment incipient motion is similar, and the underwater angle of repose is similar. The velocity of the sediment incipient motion is calculated by the use of incipient velocity formula derived by Zhang Ruijin. This formula is relatively reliable for the calculation of the velocity of sediment incipient motion for the estuary district with finer particle size and greater water depth.

The bed material in the transition section of the river mouth of Pearl River Delta is the coarsest in Dongjiang River, which belongs to middle shoal. The median diameter of waterway in Dongguan is $0.34 \mathrm{~mm}$; the bed material in Tanjiang River is the finest, which belongs to silt. The median diameter of waterway with the highest frequency in Yinzhou Lake is $0.01 \mathrm{~mm}$; the median diameter of the bed material with the highest frequency in Xijiang and Beijing River is $0.1 \mathrm{~mm}$. The median diameter of bed sand in the estuary section of the Yangtze River gradually becomes finer from upstream to downstream on the whole. According to the analysis of bed sand near Wusong estuary, the particles with the size of 0.10 to $0.25 \mathrm{~mm}$ are the most common, which gradually decrease towards the downstream. The sediment in Hangzhou Bay is mainly from the Yangtze River estuary. The bed material in this river reach is more uniform, with an average median diameter of approximately $0.049 \mathrm{~mm}{ }^{[13]-[14]}$. In summary, the bed materials in major estuaries are mostly fine sand and fine silt. If the size of model sand selected is too thin, the model sand is prone to be dense and hardened in the testing process. This research adopts fine coal dust in Zhuzhou as model sand, with the volume weight of $1.35 \mathrm{t} / \mathrm{m}^{3}$ and the median diameter of $0.5 \mathrm{~mm}$. The laying process of the model sand is simple, the underwater disturbance is not dense, and the long-term immersion is also not hardened, which can meet the requirements of repeatability of the sediment test. When the water depth is $5 \mathrm{~cm}$ to $15 \mathrm{~cm}$, the incipient velocity of the model sand is $10.31 \mathrm{~cm} / \mathrm{s}$ to $11.30 \mathrm{~cm} / \mathrm{s}$. The model sand is equivalent to the prototype sand with the median diameter of $0.25 \mathrm{~mm}$.

\subsection{Generalization of test flow conditions}

In the transmission process of China's coastal tidal waves due to the impact of Coriolis force, complex submarine topography and tortuous coastline, the tide in China's bay has the following basic features: many types of tide, obvious changes in tidal range and obvious inequality of tide and so on. After the tidal wave entering the estuary, it forms a complex and unique tidal phenomenon at estuaries and transition sections under the impact of river-bed deformation, frictional effect and runoff discharged upstream, so there is a need to generalize the tidal flow conditions.

The existing research result shows that the decisive effect of scour is the process changes of flow rate and the size of its peak, so the generalization of flow con- ditions only considers the impact of the peak value of flow rate and process, which mainly abides the following principles:

(1) The diurnal tide just fluctuates once in a tidal cycle. The longer the effective role of effective flow rate is, the better the development of the local scour at bridge pier will be, so we just do relevant tests for semi-diurnal tides.

(2) The flow rate of little fluctuation of irregular semi-diurnal tides is small, and it does not play a decisive role in the maximum scouring depth, so the regular semi-diurnal tide can be generalized as the basic type of tide.

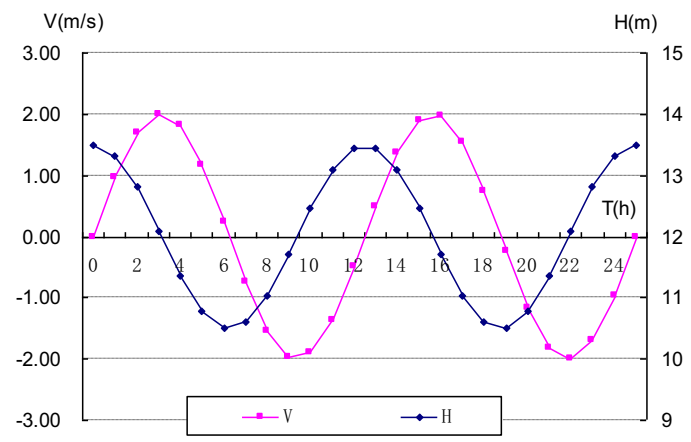

(a)

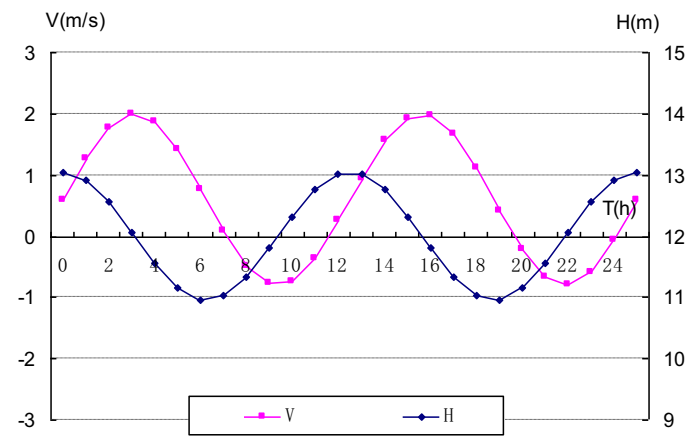

(b)

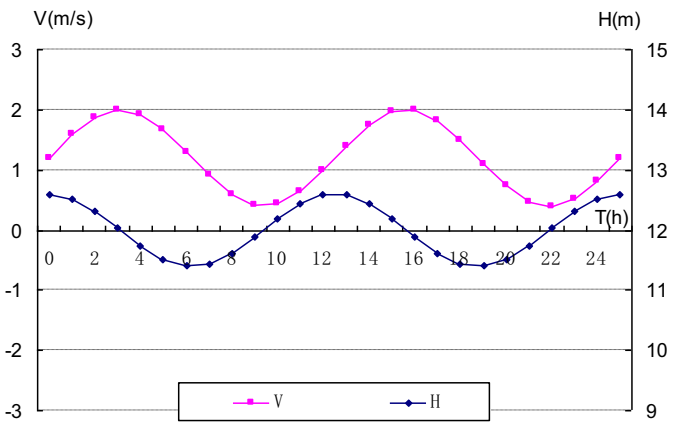

(c)

Figure 1. Test flow conditions 
EMME 2015

Table 1. Test flow conditions

\begin{tabular}{lllllll}
\hline $\begin{array}{l}\text { Hydraulogical } \\
\text { combination }\end{array}$ & $\begin{array}{l}\text { Ebb flow } \\
\text { rate }(\mathrm{m} / \mathrm{s})\end{array}$ & $\begin{array}{l}\text { Rise flow } \\
\text { rate }(\mathrm{m} / \mathrm{s})\end{array}$ & $\begin{array}{l}\text { Tidal range } \\
(\mathrm{m})\end{array}$ & $\begin{array}{l}\text { Duration of } \\
\text { ebb tide }(\mathrm{h})\end{array}$ & $\begin{array}{l}\text { Duration of } \\
\text { rising tide }(\mathrm{h})\end{array}$ & Note \\
\hline 1.5 & 1.50 & - & 0 & 25.00 & 0.00 & Constant flow \\
2.0 & 2.00 & - & 0 & 25.00 & 0.00 & \\
2.5 & 2.50 & - & 0 & 25.00 & 0.00 & \\
$1.5 \mathrm{~T}$ & 1.50 & 1.50 & 3 & 6.25 & 6.25 & Basic tide type \\
$2.0 \mathrm{~T}$ & 2.00 & 2.00 & 3 & 6.25 & 6.25 & \\
$2.5 \mathrm{~T}$ & 2.50 & 2.50 & 3 & 6.25 & 6.25 & Deformation of type \\
$1.5 \mathrm{~A}$ & 1.50 & 0.60 & 2 & 8.00 & 4.50 & of tide A \\
$2.0 \mathrm{~A}$ & 2.00 & 0.80 & 2 & 8.00 & 4.50 & Deformation of type \\
$2.5 \mathrm{~A}$ & 2.50 & 1.00 & 2 & 8.00 & 4.50 & of tide B \\
$1.5 \mathrm{~B}$ & 1.50 & - & 1.2 & 12.50 & 0.00 & \\
$2.0 \mathrm{~B}$ & 2.00 & - & 1.2 & 12.50 & 0.00 & 0.00 \\
$2.5 \mathrm{~B}$ & 2.50 & - & 1.2 & 12.50 & & \\
\hline
\end{tabular}

Note: The division of duration of ebb and flow is based on the process of tides.

(3) The process of tide and tidal level of the basic type of tide is generalized as the sine and cosine curve. When the duration of ebb and flow is reciprocal, it only considers different flow rates of fluctuation.

(4) For the basic type of tide, the trend towards the constant flow goes through twice deformation, maintains constant flow rate of ebb tide, gradually increases the duration of ebb tide, and reduces the rise flow rate and tidal range.

Accordingly, the flow conditions after generalization are shown in Table 1. To save space, Figure 1 just shows the process of type of tide with the ebb flow rate of $2.0 \mathrm{~m} / \mathrm{s}$

\section{TEST RESULT AND ANALYSIS}

\subsection{Mechanism analysis of local scour at bridge pier}

The process of formation, development and basic balance of scouring pit at bridge pier depends on the change of effective sediment runoff ${ }^{[15]}$. Under the action of constant flow, the pier forwards the near flow and underdraught flow form "pile-crossing flow". The pile-crossing flow has the maximum velocity at the forefront pile of near upstream face, and the eddy and sediment uplift are the most serious. When the flow shear stress is greater than the critical shear stress of the sediment incipient motion, the sediment around the pile is incipient. One part is taken to the downstream reserve to form sand ridge, and the other part is taken away by the mainstream. The scouring pit quickly takes shape after scouring and tends to be stable in a relatively short time. As time goes on, the volume of downstream sediment body increases, resulting in increased resistance, gradually-weakened sediment transport capacity, gradually-increased scouring depth and the range of the scouring pit, so that the sediment in the pit is increasingly difficult to be transported outside the pit. It is only locally adjusted in the scouring pit until reaching balanced scouring depth. The tidal flow only reaches the maximum value with the velocity in a certain short time. Most of the time is less than this value. Due to the impact of slack water in a certain period of ebb and flow tide, the effective time of incipient motion and transport of sediment at bed surface is significantly shorter than the time under the constant flow conditions; the effective scouring velocity and effective scouring time in the process of tide decreases, and the effective sediment runoff also decreases. Some hydrological conditions will cause sediment siltation under the action of reverse flow. The scouring balance requires longer time.

\subsection{Development process of the maximum scouring depth of local scour at pile groups}

\section{(1) Constant flow}

The development process of the depth of local scour at bridge pier under constant flow conditions is shown in Figure 2. The flow rate values are respectively $1.5 \mathrm{~m} / \mathrm{s}, 2.0 \mathrm{~m} / \mathrm{s}$ and $2.5 \mathrm{~m} / \mathrm{s}$. As can be seen from the diagram, the greater the flow rate value is, the faster the development of scouring pit is; the shorter the time is required by the scouring pit to reach relative stability, the greater the maximum scouring depth will be when the scouring pit reaches relative stability.

(2) Basic type of tide

The development process of the depth of local scour at bridge pier under different ebb and flow rate conditions is shown in Figure 3. Compared with the type of tide of $1.50 \mathrm{~T}$, the development of scouring pit for the type of tide of $2.00 \mathrm{~T}$ is rapid, the time required by the scouring pit to reach the relative stability is short, and the maximum scouring depth is great when the scour- 


\section{MATEC Web of Conferences}

ing pit reaches the relative stability. For 2.50T, the ebb (rise) flow rate is large after the energy dissipation of pile caps, which still has an impact on the downstream (upstream) scouring pit. It mainly reflects that the sediment of riverbed in the middle part of pile cap is backfilled to the scouring pit under the action of reverse flow. The depth of scouring pit gradually deepens in the process of repeated erosion. The sediment backfilling caused by the reverse flow results in slow formation of the scouring pit. So the scouring requires a longer time to reach equilibrium. With the continued development of scour, the sand dune of riverbed in the middle part of pile cap is constantly leveled by water flow and gradually pushed into downstream, so the effect of sediment backfilling caused by the reverse flow is gradually weakened and the amplitude of variation of the scouring depth decreases gradually. In the later period of the development of scouring pit, the depth of scouring pit presents a continuously increasing trend, and the amplitude of increase gradually decreases, so the sediment backfilling caused by the reverse flow does not affect the maximum scouring depth.

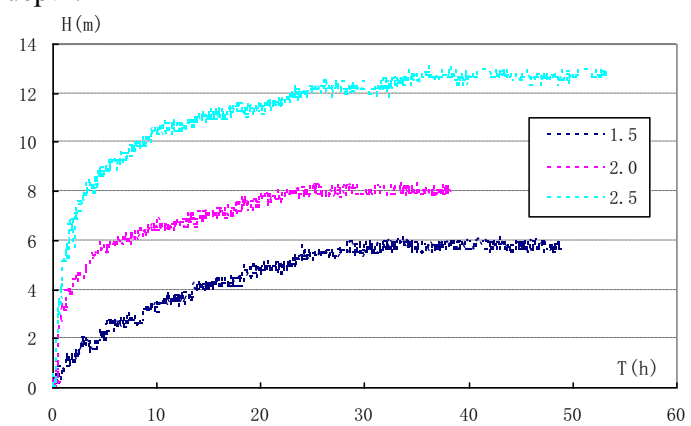

Figure 2. Development process of the maximum scouring depth of local scour at pile groups (constant current)

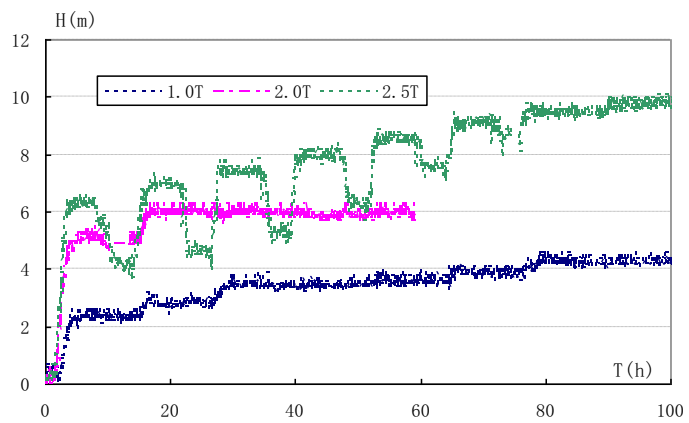

Figure 3. Development process of the maximum scouring depth of local scour at pile groups (basic type of tide)

(3) Deformation of tide type

The deformation of tide type is mainly reflected in the extension of duration of ebb tide, reduction of rise flow rate and reduction of tidal range, which can re- flect changes of the transmission process of tide from the estuary to upstream riverway, while the constant flow can be seen as a limit tide state with continuing ebb flow and tidal range of zero. Through the deformation of the tide type towards the constant flow, the differences and relations of the development process of the constant flow and scouring pit under tidal action can be observed. As can be seen from the Figure 4 $2.0 \mathrm{~T}$ is a type of tide when the duration of the ebb and flow tide is the same. In the later period of the scouring pit development, the increase rate of the scouring depth is very slow, and the deepening of the scouring pit is not obvious; the duration extension of ebb flow for $2.0 \mathrm{~A}$ is $8 \mathrm{~h}$; the whole tidal cycle of $2.0 \mathrm{~B}$ is an ebb flow process; the effective acting time of the effective flow rate of ebb tide successively increases, the development rate of the scouring pit and the final depth also increases and it is gradually close to the development process of scouring pit under the action of constant flow. The duration of the ebb and flow tide determines the development rate of scouring pit and the possibility of reaching the maximum scouring depth. When the effective acting time of flow is too short, the scouring rate will become very small after the scouring pit developed to a certain extent, and the change of scouring depth is slow; it requires a longer time for scouring to reach equilibrium, and it is even difficult to achieve the theoretical maximum scouring depth, therefore, the reduction coefficient of the scouring pit is less than 1

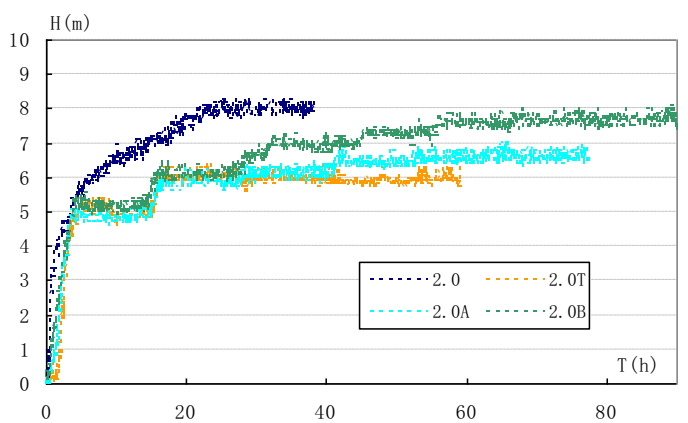

Figure 4. Development process of the maximum scouring depth of local scour at pile groups (deformation of type of tide)

3.3 Relationship between the tide and the depth of local scour at bridge pier under the action of constant flow

The ratio between the depth of local scour at bridge pier under tidal action and the depth of local scour at bridge pier under the action of constant flow is the "reduction coefficient", that is: 0.75--1.00. For the same duration of ebb tide, the greater the ebb flow rate is, the greater the depth of local scour at bridge pier is; for the same ebb flow rate, the greater the duration of ebb flow is, the closer to 1 of the reduction coefficient it will be. The test shows that the maximum local 
EMME 2015

Table 2. Ratio between the tide and the depth of local scour at pier groups under the action of constant flow

\begin{tabular}{lllllll}
\hline No. & $\begin{array}{l}\text { Hydraulogical } \\
\text { combination }\end{array}$ & Ebb flow rate $(\mathrm{m} / \mathrm{s})$ & Rise flow rate $(\mathrm{m} / \mathrm{s})$ & Tidal range $(\mathrm{m})$ & $\begin{array}{c}\text { Scouring } \\
\text { depth(m) }\end{array}$ & $\begin{array}{c}\text { Reduction } \\
\text { coefficient }\end{array}$ \\
\hline 1 & 1.5 & 1.50 & - & 0 & 6.1 & - \\
2 & 2.0 & 2.00 & - & 0 & 8.3 & - \\
3 & 2.5 & 2.50 & - & 0 & 13.1 & - \\
4 & $1.5 \mathrm{~T}$ & 1.50 & -1.50 & 3 & 4.6 & 0.75 \\
5 & $2.0 \mathrm{~T}$ & 2.00 & -2.00 & 3 & 6.4 & 0.77 \\
6 & $2.5 \mathrm{~T}$ & 2.50 & -2.50 & 3 & 10.2 & 0.78 \\
7 & $1.5 \mathrm{~A}$ & 1.50 & -0.60 & 2 & 5.4 & 0.8 \\
8 & $2.0 \mathrm{~A}$ & 2.00 & -0.80 & 2 & 1.1 & 0.86 \\
9 & $2.5 \mathrm{~A}$ & 2.50 & -1.00 & 2 & 1.9 & 0.91 \\
10 & $1.5 \mathrm{~B}$ & 1.50 & - & 1.2 & 5.9 & 0.97 \\
11 & $2.0 \mathrm{~B}$ & 2.00 & - & 1.2 & 8.1 & 0.98 \\
\hline
\end{tabular}

scouring depth at bridge pier under tidal action depends on the strongest hydrodynamic conditions of ebb and flow tide. That is, when the ebb and flow rate and duration and the maximum flow rate of flow and mean flow rate of one-way constant flow are equal, both of the maximum scouring depth are basically the same.

\section{CONCLUSION AND SUGGESTION}

(1) The research on the characteristics of local scour at bridge pier under tidal action and the scouring depth is an emerging research direction, which will play a guiding role in the design and protection of the bridges in the estuaries and coastal areas.

(2) The process of local scour at bridge pier depends on the changes of sediment runoff in the scouring pit. Due to reduction in the effective time of effective flow rate in the process of tide, the effective sediment runoff will significantly reduce, so that the overall scouring process will extend under tidal action, and the scouring requires a longer time to reach equilibrium.

(3) The maximum flow rate of ebb and flow tide and duration determines the development rate of scouring pit and the possibility of reaching the maximum scouring depth. When the tide flow rate is large or the duration is dominant, the maximum local scouring depth that is consistent with the constant flow will be obtained. In calculating the depth of local scour at bridge pier, for safety's sake, the mean flow rate is replaced by the rise flow rate, and the calculation adopts the formula recommended in the Specifications.

(4) The local scour at bridge pier is not only related to the hydrology, the type of river, the anti-shock capacity of the sediment and the riverbed geology, but also closely related to the type of pier, the height of the pile cap and the construction program and so on. For the grand bridges with complex hydrology and sediment conditions that are difficult to determine the coefficient of pier type, the scouring depth can be determined by the hydraulic model tests.

\section{REFERENCES}

[1] Gao Dongguang, \& Wang Yaling. 2008. Hydrology for bridge and culvert. Beijing: China Communications Press, 12.

[2] Industry Standards of the People's Republic of China, Hydrological Survey and Design Specifications of Highway Engineering, JTG C30-2002, Ministry of Transportation of the People's Republic of China, 2002.5.1

[3] Wang Qun, Huang Chongyou, Lin Guibin, \& Dai Rongyao. 1987. Experimental research on the pier tidal scour of Myanmar Yangon - Thanlyin Bridge, Academy of Railway Sciences, 12 .

[4] Wang Qun, et al. 1989. Experimental research on local scouring depth of Shantou Mayu Bridge Pier, Academy of Railway Sciences, 11

[5] Dong Zhihui, 2009. Mobile bed river model test of Qinglan Bridge in Wenchang City of Hainan Province and research report of local scour at bridge pier, Pearl River Hydraulic Research Institute of the Pearl River Water Resources Commission, June.

[6] A. Melih Yanmaz \& H. Dogan Altmbilek, 1991. Study of time-Dependent local scour around bridge piers, Journal of Hydraulic Engineering, Vol.112.No10, October.

[7] Lu Zhongyi, Gao Zhengrong, \& Huang Jianwei. 2006. Experimental research report of local scour of large pile group foundation under tidal action, Nanjing Hydraulic Research Institute, 7.

[8] Gao Zhengrong, Huang Jianwei, \& Lu Zhongyi. 2005. Research of local pier and protection at bridge pier of river-spanning bridge at Yangtze River estuary, Maritime Press, August.

[9] Xu Zheng, \& Liang Bin. 2010. Experimental research of local scour at bridge pier of Jiuzhoubao Bridge of Hangzhou City, Zhejiang Hydraulic Science and Technology, Phase 4, a total of 17, July 13-17 


\section{MATEC Web of Conferences}

[10] Jiang Xiaojun, Liu Nan, Liu Renyi, Han Haiqian, \& Hu Jianjiong, 2010. Research of model verification method for local scour at bridge pier in strong tidal areas, Journal of Zhejiang University, Phase 1 of Vol. 37, January $113-116$

[11]E.V. Richardron, J.R. Richardron. \& P.F. Lagasse. 2000 Bridge Scour Evaluation in the United States, Scour of Foundations proceedings of an International Symposium organized by the International Society of Soil mechanics and Geotechnical Engineering Technical committee Tc-33 on Sour of Foundations, 11, Mellourne Australia.
[12]Han Haiqian. 2006. Research on local scour at bridge pier under tidal action. Postgraduate thesis of Zhejiang University, 8.

[13]Chen Jiyu. 2007. Research and Practice of Chinese Estuary and Coast. Beijing: Higher Education Press.

[14]Chen Zeshi, Wang Wenhai, \& Wu Sangyun. 2007. Introduction to China Bay. Beijing: Maritime Press, 5.

[15] Comprehensive analysis of the research of local scour at bridge pier and case analysis and calculation, Nanjing Hydraulic Research Institute, September 2011. 